\title{
Sikap Pilihan Bahasa Pelaku Ekonomi Berdasarkan Tinjauan Undang-Undang dan Peraturan Pemerintah
}

\author{
Eka Dian Savitri ${ }^{1}$, Kartika Nuswantara $^{2}$, Siti Zahrok ${ }^{3}$ \\ Institut Teknologi Sepuluh Nopember Surabaya \\ UPT PMK Sosial Humaniora, Institut Teknologi Sepuluh Nopember, 61111, Surabaya, E-mail: \\ ekadian04@gmail.com
}

\begin{abstract}
This is a descriptive qualitative study that aims to describe Indonesian economists language attitude, specifically on the way they label the products. By means of behaviorist approach, the study raises an interpretation of the economists throughot observation. In order to come to the answer of the problem, data employed in this present study is the secondary data derived from other researchers. Then, the analysis of the data is employed by reviewing the labeling process in three ways, namely reasons for labeling, characteristics of the language attitude, and the Act 24 year 2009. It is figured out that there are 29 products labeled using foreign words or phrase, and the rest 11 products use Indonesia language. The phenomenon shows that labeling in foreign languages would enhance the positive image of the product. On the other hand, positive attitude is shown by the economists through their loyalty using bahasa Indonesia for labelling. Final finding is to show that the attitude displays the conterproductive to the Act 24 of 2009.
\end{abstract}

Keywords: language attitude, economists, act 24 of 2009

Abstrak
Tulisan ini mendeskripsikan sikap pilihan bahasa pelaku ekonomi terhadap pemakaian bahasa serapan atau bahasa Indonesia dalam melabeli produk yang dihasilkan. Dengan memanfaatkan pendekatan behavioris untuk sampai pada interpretasi sikap bahasa, peneliti memakai data sekunder untuk melihat bagaimana pelaku ekonomi melabeli produkproduk yang dihasilkan. Kajian atau analisis yang dipakai untuk menilai sikap bahasa tersebut adalah alasan pelabelan dengan bahasa asing, karakteristik yang terlibat, dan tinjauan undang-undang. Penelitian yang memperoleh hasil 40 label, 29 diantaranya memakai bahasa asing dan 11 nama produk mempertahankan bahasa Indonesia. Fenomena ini dipahami sebagai upaya menciptakan citra produk melalui bahasa asing. Sedangkan sikap positif ditunjukkan bagi pelaku ekonomi yang masih mempertahankan bahasa Indonesia, dan terakhir bagaimana temuan ini menunjukkan sikap pilihan bahasa yang bertentangan dengan kebijakan bahasa dalam Undang-Undang No.24 Tahun 2009.

Kata Kunci: sikap pilihan bahasa, pelaku ekonomi, undang-undang bahasa

\section{Pendahuluan}

Tantangan globalisasi Masyarakat

Ekonomi Asean (MEA) mendorong setiap bangsa untuk masuk ke dalam pusaran pergaulan internasional baik secara langsung maupun tidak langsung sehingga kontak budaya menjadi hal yang tidak dapat dihindari, begitu pula pengaruhnya dalam komunikasi masyarakat Indonesia. Kecenderungan masyarakat Indonesia yang terbuka terhadap budaya asing memiliki dampak langsung terhadap kebudayaan Indonesia salah satunya adalah hegemoni bahasa asing terhadap bahasa-bahasa yang ada di Indonesia. Salah satu fenomena ini dapat dilihat di sekitar kita dimana istilah-istilah bahasa asing menjadi lebih populer di kalangan masyarakat karena dianggap dapat meningkatkan prestise seseorang. Dengan alasan internasionalisasi dan menyambut MEA, penamaan tempat di sekitar fasilitas umum, nama bangunan (hotel, rumah sakit, rumah makan, atau pusat perbelanjaan), iklan pada baliho sepanjang jalan, dan masih banyak media lain memilih menggunakan istilah berbahasa Inggris daripada mempertahankan pemakaian bahasa Indonesia. 
Dengan semakin merebaknya pemakaian bahasa asing, pada saat yang sama pergeseran pemakaian istilah berbahasa Indonesia tidak dapat dihindari.

Menurut Fasold (1984:213) dalam konteks pergeseran bahasa, bahasa yang memiliki status lebih tinggi dan dianggap bergengsi oleh masyarakat secara perlahan akan menggeser bahasa yang statusnya lebih rendah. Hal ini dapat diilustrasikan sebagai berikut, bahasa yang dianggap bergengsi seperti bahasa asing memiliki kecenderungan menggeser bahasa Indonesia, serta bisa juga bahasa Indonesia yang dianggap lebih bergengsi juga memiliki kecenderungan menggeser bahasa daerah. Kondisi demikian bukan disebabkan oleh sifat dan struktur masing-masing bahasa yang dianggap lebih rumit atau lebih mudah, tetapi lebih banyak dipengaruhi oleh sikap berbahasa kelompok tutur atau masyarakat bahasa. Berkaitan dengan sikap berbahasa tersebut, Fasold menyebutkan bahwa sikap berbahasa bukan hanya merupakan sikap terhadap bahasa, akan tetapi konsep sikap berbahasa lebih sering meliputi sikap terhadap penutur suatu bahasa, atau secara lebih luas dipahami bahwa sikap berbahasa mencakup semua jenis sikap yang berhubungan dengan perlakuan terhadap bahasa tersebut.

Terdapat dua jenis pendekatan terhadap sikap berbahasa yaitu pendekatan behavioris dan mentalis (Fasold, 1984; Ihemere, 2006). Berdasarkan pendekatan behavioris, sikap berbahasa dijumpai pada respon atau tanggapan seseorang terhadap situasi sosial. Penelitian dengan pendekatan ini lebih mudah dilaksanakan mengingat penelitian ini tidak mengharuskan laporan responden, melainkan peneliti cukup melakukan pengamatan langsung, tabulasi, dan analisis terhadap sikap yang tampak. Hal ini berbeda dengan pendekatan mentalis dimana sikap ditinjau dari keadaan mental seseorang sehingga untuk mengetahui sikap yang mendasari tanggapan atau respon seseorang diperlukan penelitian dengan cara memberikan stimulasi sehingga respon dapat dimunculkan (Fasold. 1984 and Ihmere, 2006). Penelitian kali ini mengkhususkan pendekatan behavioris untuk melihat sikap berbahasa sekelompok masyarakat terhadap situasi tertentu, lebih tepatnya yaitu sikap pilihan bahasa pelaku ekonomi terhadap pemakaian bahasa dalam produk-produk yang dihasilkan.

Sikap berbahasa masyarakat dipengaruhi oleh berbagai faktor seperti lingkungan berbahasa, ilmu pengetahuan, teknologi, kecepatan dan sarana informasi, pendidikan, status sosial, kebijakan politik, dan lainnya. Faktor-faktor tersebut berkembang mengikuti perkembangan jaman. Fenomena ini tidak hanya terjadi di Indonesia tetapi juga terjadi di semua masyarakat bahasa di dunia. Di sisi lain, perubahan bahasa merupakan sebuah keniscayaan dan tidak dapat dihindari karena bahasa merupakan produk pikiran masyarakat dan keberadaannya terikat dengan kondisi kebahasaan penggunanya. Namun demikian perubahan tersebut tetap dapat dikendalikan dan dikelola agar sesuai dengan yang diharapkan. Hal ini bertujuan agar bahasa Indonesia tetap dapat memelihara kedaulatannya serta menjaga fungsinya sebagai bahasa negara dan bahasa nasional. Oleh karena itu untuk menjalankan fungsinya, bahasa Indonesia perlu 
didukung dengan seperangkat kebijakan pembinaan dan pelestarian bahasa.

Seperangkat kebijakan dan aturan perundang-undangan yang dibuat oleh pemerintah digunakan untuk melindungi bahasa Indonesia dari pengaruh buruk sikap berbahasa masyarakat yang cenderung mengagumi dan memuja segala sesuatu yang berbau asing termasuk bahasa asing atau dikenal dengan xenofilia (Suprana, 1998:269). Xenofilia dalam hal ini memiliki pengertian kecenderungan kelompok masyarakat yang menganggap bahasa asing lebih baik dan lebih utama dibandingkan bahasa dan kebudayaan sendiri. Kelompok masyarakat tersebut cenderung mengagung-agungkan dan memuja bahasa asing sehingga mempengaruhi sikap dan perilaku berbahasa sehari-hari. Gejala-gejala xenofilia dalam pemakaian bahasa asing sering dijumpai dalam berbagai bidang komunikasi utamanya seperti bidang komunikasi ekonomi.

Perlindungan yang diberikan pemerintah terhadap bahasa Indonesia salah satunya adalah dengan mengesahkan Undang-Undang No. 24 tahun 2009 Bab III tentang Bahasa, yang mengatur secara umum tata cara penempatan penggunaan bahasa Indonesia, bahasa asing, dan bahasa daerah. Undang-undang tersebut mengukuhkan kedudukan dan fungsi bahasa Indonesia sebagai bahasa tertinggi dalam sistem komunikasi nasional. Undang-undang tersebut juga memperjelas bahwa kedudukan dan fungsi bahasa Indonesia tidak dapat digantikan oleh bahasa asing. Sementara itu, bahasa asing digunakan hanya sebagai pelengkap bahasa Indonesia dan sarana komunikasi internasional.
Secara khusus, sikap berbahasa Indonesia oleh pelaku ekonomi dalam penelitian ini akan dipersepsikan sebagai sikap pilihan bahasa pelaku ekonomi. Penelitian ini bertujuan untuk mencari jawaban atas beberapa pertanyaan berkaitan dengan sikap berbahasa terhadap pemakaian bahasa Indonesia dan bahasa asing. Secara lebih spesifik, penelitian ini bertujuan untuk melihat implementasi Undang-Undang No 24 tahun 2009 terhadap penamaan produk sebagai refleksi dari sikap berbahasa kelompok masyarakat tertentu, dalam hal ini pelaku ekonomi.

\section{Definisi dan karakteristik sikap bahasa}

Definisi sikap menurut KBBI (http://kbbi.web.id/sikap) adalah cara berdiri (tegak, teratur, atau dipersiapkan untuk bertindak), perbuatan dan sebagainya yang berdasarkan pada pendirian, keyakinan, perilaku, gerak-gerik; bertingkah laku dengan gaya yang dibuat-buat (supaya tampak gagah dan sebagainya). Jadi "sikap" diidentikkan dengan perilaku dan perbuatan yang berdasarkan pada keyakinan dan pendirian dengan tujuan tertentu. Hal ini sejalan dengan pendapat Chaer dan Agustina (2004) yang menyatakan bahwa sikap merupakan posisi kejiwaan atau mental yang termanifestasi ke dalam perilaku atau tindakan.

Posisi mental dipengaruhi oleh konteks yang melingkupinya seperti pengalamanpengalaman masa lalu, situasi yang terjadi, dan keinginan atau harapan di masa depan (Azwar, 2007). Menurut Lambert (1967) sikap memiliki tiga komponen pembentuk yaitu: komponen kognitif, komponen afektif, dan komponen konatif. 
Komponen kognitif merupakan pengetahuan atau disebut juga dengan pengalaman-pengalaman yang dimiliki terkait dengan lingkungan sekitar serta gagasan yang digunakan dalam proses berpikir. Komponen afektif merupakan respon yang dihasilkan berupa penilaian baik atau buruk, suka atau tidak suka, yang dikenal dengan sikap positif atau negatif. Komponen konatif merupakan respon yang dihasilkan berupa perilaku atau tindakan. Berdasarkan kedua pendapat tersebut, dapat diketahui sikap individu atau kelompok melalui perilaku atau tindakannya

Sikap masyarakat dapat disimpulkan berdasarkan komponen-komponen bahasa dan konteksnya. Dengan kata lain, sikap bahasa dapat disimpulkan melalui pengalaman, penilaian, dan perilaku yang dihasilkan seseorang atau kelompok terhadap suatu bahasa. Menurut Kridalakasana (2001:197) sikap bahasa adalah posisi mental atau perasaan terhadap bahasa sendiri atau bahasa orang lain. Posisi mental atau perasaan dapat diwujudkan dalam bentuk perilaku berbahasa, misalnya seseorang yang menguasai multibahasa akan condong menyukai dan memilih menggunakan salah satu bahasa untuk menonjolkan status atau pendidikannya, sedang bahasa lain digunakan untuk mengakrabkan diri dengan lawan bicaranya. Oleh karena itu sikap bahasa dapat tercermin melalui perilaku berbahasanya. Pendapat lain menyatakan bahwa sikap bahasa individu tidak selalu mencerminkan sikap bahasa kelompok masyarakat karena terkait dengan posisi mental atau perasaan yang tidak dapat diukur. Namun bila dilihat lebih jauh, perilaku berbahasa yang diulang secara terus menerus akan dianggap sah dan menjadi sebuah kebiasaan yang akhirnya dianggap sebagai kebenaran subyektif. Kebenaran ini semakin sering akan membangun komponen kognitif seseorang dan memasukkannya sebagai bagian dari pengalaman yang lambat laun akan menjadi kebenaran obyektif. Dari sinilah, dapat diketahui perilaku berbahasa masyarakat yang terdiri dari kumpulan-kumpulan sikap individu atau kelompok dengan mengacu pada kesamaan umum.

Karakteristik sikap bahasa dari sudut pandang pengertian bahasa merupakan sikap mental dan rasa tentang posisi bahasa seseorang terhadap bahasa orang lain (Kridalaksana, 2008). Sikap dapat dipahami sebagai sesuatu yang abstrak maka hanya dapat diamati melalui perilaku, meskipun tidak berlaku sebaliknya; perilaku tidak selalu mencerminkan sikap. Maricar menyitir Garvin dan Mathiot (1968) bahwa terdapat tiga karakteristik sikap bahasa yang mengindikasikan sikap positif terhadap bahasa, yaitu:

a. Loyalitas bahasa yang mendorong seseorang untuk mempertahankan bahasanya, dan mencegah pengaruh bahasa lain.

b. Kebanggaan bahasa yang mendorong seseorang untuk mengembangkan bahasanya dan menggunakan bahasa tersebut sebagai identitas bangsa atau masyarakatnya.

c. Kesadaran bahasa yang mendorong seseorang untuk mempergunakan bahasanya secara hatihati dan dengan kesopanan. Dan faktor ini menjadi penentu terbesar yang berpengaruh pada pemakaian bahasa.

Gejala-gejala sikap bahasa kelompok masyarakat dapat diketahui dengan 
mengumpulkan fakta perilaku-perilaku bahasa individu. Perilaku bahasa tidak hanya fokus pada bahasa dan ragam bahasa namun juga memperhatikan aspek di luar struktur bahasa. Sejak lama, para linguis mengkaji hubungan bahasa dan konteks penggunaannya untuk mengetahui bagaimana dan dengan alasan dan tujuan apa bahasa tersebut digunakan. Salah satunya yang cukup dikenal adalah M.A.K Halliday. Halliday dalam Halliday dan Hasan (1985) mengemukakan pendapatnya dengan melakukan penekanan pada konteks sosial bahasa. Menurutnya bahasa merupakan produk sosial, oleh karena itu ia melekat pada sistem sosial. Bahasa juga dipandang sebagai realitas sosial, hasil dari konstruksi masyarakat yang dikodekan lalu dimaknai sesuai dengan pengetahuan dan pengalaman masing-masing partisipan. Halliday lalu membagi komponen bahasa berupa teks dan konteks. Teks adalah unit bahasa yang sedang melakukan fungsinya dalam konteks situasi, sedangkan konteks adalah situasi tempat teks menjalankan fungsinya (Halliday dan Hasan, 1992). Mengulas teks dalam konteks dapat menjelaskan siapa, mengapa, dan dengan tujuan apa bahasa asing lebih disukai dalam bidang ekonomi dibandingkan bahasa Indonesia.

\section{Beberapa Studi dan Kajian Tentang Sikap Bahasa}

Dalam tulisannya, Ihemere (2006) menyampaikan bahwa Fasold (1984: 147 -148) dan Agheyisi dan Fishman (1970 :138) sependapat menyebutkan adanya dua pendekatan, yaitu pendekatan behavioris dan mentalis yang dipergunakan dalam melihat sikap bahasa seseorang atau kelompok masyarakat. Mereka menyebutkan bahwa pendekatan behavioris memandang perilaku bahasa sebagai pendekatan terhadap sikap bahasa melalui observasi langsung sehingga tidak memerlukan keterlibatan langsung obyek penelitian untuk memberikan makna dari sikap bahasa tertentu. Pendekatan ini hanya mampu memberikan interpretasi sikap yang mampu diobservasi. Sedangkan pendekatan mentalis lebih mampu memberikan interpretasi lebih luas mengingat pendekatan ini melibatkan subyek penelitian untuk ikut membantu peneliti mencapai berbagai kemungkinan makna atau interpretasi makna dari sikap bahasa tertentu. Seperti yang dideskripsikan oleh Fasold (1984) dan beberapa peneliti lain seperti Gao \& Zhou (2000) in Wang a \& Hans J. Ladegaard (2010).

Sebuah penelitian tentang sikap bahasa dihubungkan dengan perubahan bahasa telah dilakukan oleh Maricar (2016). Penelitian ini mencari faktor-faktor berpengaruh perubahan bahasa di Kota Ternate. Penelitian ini mengungkapkan sikap berbahasa sebuah kelompok masyarakat. Bahasa ibu di sebuah wilayah di Ternate mulai ditinggalkan oleh penutur aslinya, dan secara kolektif masyarakat Ternate menggunakan bahasa lain sehingga mengakibatkan pergeseran bahasa pada bahasa lokal di Ternate. Penelitian tersebut menghasilkan identifikasi faktor yaitu faktor eksternal dan internal. Faktorfaktor tersebut meliputi faktor budaya, ekonomi, sejarah, bentuk perkawinan, lokalitas, keberlanjutan, dan transfer intergenerasi sebagai 
faktor eksternal. Sedangkan faktor internal meliputi motivasi, kebiasaan berbahasa, sikap bahasa, serta ketrampilan berbahasa. Kedua faktor tersebut dianggap sebagai faktor kontributif terhadap perubahan bahasa di Ternate.

\section{Metode Penelitian}

Penelitian ini merupakan penelitian deskriptif sehingga seperti yang disebutkan oleh Bogdan dan Biklen (1990), maka penelitian ini mencoba memaparkan fenomena, situasi, atau peristiwa yang telah ada tanpa perlu melakukan manipulasi data atau fenomena tersebut. Penelitian ini juga tidak menguji hipotesis atau prediksi, melainkan penelitian ini bertujuan untuk (1) mengumpulakn informasi secara mendalam dan memberikan deskripsi gejala yang ada, kemudian melakukan identifikasi atau pengelompokan, melalukan perbandingan atau mengevaluasi, kemudian menghasilkan simpulan berdasarkan hasil pengamatan atau survei. Jenis data yang dipergunakan adalah data kualitatif, sehingga data dalam penelitian ini berupa kata-kata bukan angka. Data merupakan data sekunder yang diambil dari pengamatan yang dilakukan seseorang dan diunggah dalam laman pribadi (http://www.ririekhayan.com/2015/10/memperlua s-spirit-local-brand-lebih.html),

(https://core.ac.uk/download/files/886/35389457.p df) dan Sari (2014). Analisis data dilakukan dengan memulai pengelompokan data ke dalam dua kelompok yaitu penamaan produk dari bahasa asing dan bahasa Indonesia. Kategori penamaan produk diambil dari sejumlah nama produk yang telah mampu merambah pasar internasional.

\section{Pembahasan}

Sikap masyarakat Indonesia sejak lama digambarkan oleh Suprana (1998:269) sebagai masyarakat yang cenderung mengagumi hal-hal yang berbau asing. Karakter masyarakat Indonesia yang ramah dan terbuka disertai dengan mobilisasi yang cukup tinggi membuat kontak ekonomi, sosial, budaya masyarakat antarnegara turut menyebabkan terjadinya kontak bahasa. Kontak bahasa di satu sisi memberikan dampak positif salah satunya adalah memperkaya kosakata bahasa Indonesia, sedangkan di sisi lain juga rentan berdampak negatif yaitu terjadinya subordinasi bahasa Indonesia oleh bahasa asing yang ditandai dengan meletakkan bahasa Indonesia pada posisi kedua dalam aktivitas kebahasaan masyarakat Indonesia. Kondisi demikian dikhawatirkan akan dapat menggeser posisi dan kedudukan bahasa Indonesia sebagai bahasa utama nasional di masyarakat. Dalam kajian sosiolinguistik, pergeseran bahasa dimulai dengan sikap negatif masyarakat terhadap satu bahasa dan menonjolkan sikap positif terhadap bahasa yang lain (bahasa asing).

\section{Penggunaan Bahasa Asing pada Nama Merek Produk dan Label Informasi}

Foreign branding biasa digunakan untuk mengenalkan produk baru yang seringkali spesifikasinya tidak berbeda dengan produk yang sudah lebih dulu ada. Foreign branding digunakan untuk menarik minat konsumen dengan 
mencitrakan nama merek dan memainkan persepsi konsumen. Menurut Viller et al (2012) foreign branding merupakan strategi yang dilakukan oleh pemilik usaha untuk membentuk citra positif produk sesuai dengan kualitas produk asing dari negara tertentu yang dipersepsikan unggul. Secara psikologis, pemilihan nama merek berbahasa asing oleh pelaku usaha merupakan upaya strategi pemasaran untuk memikat hati konsumen. Strategi foreign branding di Indonesia bertentangan dengan amanat Undang-Undang No. 24 Tahun 2009 Bab III Tentang Bahasa Pasal 36 ayat 3 yang menyatakan bahwa: Bahasa Indonesia wajib digunakan untuk nama bangunan atau gedung, jalan, apartemen atau permukiman, perkantoran, kompleks perdagangan, merek dagang, lembaga usaha, lembaga pendidikan, organisasi yang didirikan atau dimiliki oleh warga negara Indonesia atau badan hukum Indonesia.

Selanjutnya, terdapat 40 nama produk dari berbagai jenis usaha yang dipilih berdasarkan penyebaran pemasaran produk hingga keluar negeri dan penamaan produk dengan pemakaian kata asing dan bahasa Indonesia. Berdasarkan tabel 1, diperoleh data dengan kategori nama produk dengan memakai penamaan bahasa asing yang telah merambah pasar luar negeri sejumlah sejumlah 19 nama produk, 5 nama produk berbahasa asing yang ditujukan untuk pasar dalam negeri dan juga luar negeri (WNA). Berikutnya, 11 nama produk yang telah masuk dalam lingkup pemasaran luar negeri dengan mempertahankan bahasa Indonesia. Dan terakhir, 5 nama produk dengan bahasa asing meskipun belum memasuki pasar luar negeri.

Tabel 1. Daftar Data Nama Produk Dalam Negeri dengan Istilah Bahasa Serapan dan Bahasa Indonesia

\begin{tabular}{|c|c|c|c|c|}
\hline \multirow[t]{2}{*}{ No } & \multirow{2}{*}{$\begin{array}{c}\text { Sebaran Pemasaran } \\
\text { Produk }\end{array}$} & \multicolumn{3}{|c|}{ Nama Produk } \\
\hline & & Bahasa Asing & & Bahasa Indonesia \\
\hline 1. & \multirow{19}{*}{ Pasar Luar Negeri } & Polytron & 30. & "Garuda Indonesia \\
\hline 2. & & Extra Joss & 31. & Kopiko \\
\hline 3. & & Aqua & 32. & Indomie \\
\hline 4. & & JCO Donut and Coffee & 33. & Teh botol \\
\hline 5. & & Polygon & 34. & Kapal Api \\
\hline 6. & & Bagteria & 35. & Tolak Angin \\
\hline 7. & & Silver Queen & 36. & Semen Indonesia \\
\hline 8. & & Essanza & 37. & 77 Es Teller \\
\hline 9. & & Good Year & 38. & Dua Kelinci \\
\hline 10. & & Eiger & 39. & Mustika Ratu \\
\hline 11. & & Lea & 40 & Tolak Angin \\
\hline 12. & & Peter Says Denim & & \\
\hline 13. & & The Executive & & \\
\hline 14. & & Hammer & & \\
\hline 15. & & Surfer Girl & & \\
\hline 16. & & Bucceri & & \\
\hline 17. & & Bodypack & & \\
\hline 18. & & Casablanca & & \\
\hline 19. & & Excelso & & \\
\hline 20. & \multirow{5}{*}{ Pasar Dalam Negeri } & Paseo & & \\
\hline 21. & & Papa Ron's Pizza & & \\
\hline 22. & & Jordan Bakery & & \\
\hline 23. & & Yophie Salon & & \\
\hline 24. & & Sophie Martin & & \\
\hline
\end{tabular}




\begin{tabular}{|c|c|c|}
\hline 25 & \multirow{5}{*}{$\begin{array}{l}\text { Pasar Dalam Negeri } \\
\text { dan atau Luar Negeri }\end{array}$} & The Peak Residence \\
\hline 26 & & Klaska Residence \\
\hline 27 & & Belleview Manyar \\
\hline 28 & & Cornell Apartment \\
\hline 29 & & Denver Apartement \\
\hline
\end{tabular}

Pendekatan behavioris yang dipergunakan peneliti untuk memaknai sikap bahasa para pelaku ekonomi melalui nama produk yang dipilih untuk mem-branding produk yang dihasilkan menggiring pada sebuah interpretasi bahwa pemakaian istilah dari bahasa asing cenderung lebih banyak dipilih sebagai upaya untuk memperkenalkan produk hingga pasar luar negeri. Temuan ini selaras atau mendukung temuan dari penelitian yang dilakukan oleh Yenata dan Herawati (https://core.ac.uk/download/files/886/35389457.p df) berupa penelitian tentang satu merek bernama Zupparella menyimpulkan bahwa hubungan strategi pemasaran dengan nama merek (citra merek) Zupparella yang berasosiasi dengan bahasa asing telah memengaruhi ketertarikan konsumen terutama anak muda. Hal ini merupakan gambaran alasan sebagian para pengusaha lebih memilih menggunakan merek berbahasa asing dibandingkan bahasa Indonesia sebagai merek lokal. Tetapi perlu diketahui, bahwa sisi lain dari hasil penelitian menyimpulkan bahwa strategi foreign branding tidak akan berhasil bila tidak didukung dengan kesesuaian nama merek (citra merek) dengan harga, kualitas, dan sasaran yang tepat.

Selanjutnya data yang terkumpul dianalisis menggunakan tiga parameter meliputi karakteristik sikap bahasa seperti yang disebutkan oleh Maricar dengan menyitir Garvin dan Mathiot (1968). Para pelaku ekonomi yang masih mempertahankan pemakaian bahasa Indonesia memiliki sikap positif dengan karakteristik yakni loyal terhadap bahasa Indonesia sehingga produk yang dipasarkan di luar negeri masih memilih nama dengan istilah bahasa Indonesia. Pada saat yang sama, kebanggaan bahasa dari para pelaku ekonomi ini menjadi sikap positif yang ditunjukkan dengan keberanian untuk menjadikan identitas melalui pemertahanan bahasa Indonesia pada nama produk. Pelaku ekonomi yang memilih bahasa asing tidak menunjukkan sikap positif terhadap bahasa Indonesia namun alasan pemilihan bahasa asing lebih dipahami sebagai kebutuhan pasar seperti yang tersebut pada penelitian terdahulu (cf. Yenata dan Herawati).

Bahasa asing dalam produk tidak hanya digunakan dalam penamaan merek, tetapi juga untuk pelabelan produk atau keterangan produk. Label adalah setiap keterangan mengenai barang yang berbentuk gambar, tulisan, kombinasi keduanya, atau bentuk lain yang memuat informasi tentang barang dan keterangan pelaku usaha serta informasi lainnya sesuai dengan ketentuan peraturan perundang-undangan yang berlaku. Biasanya barang yang menggunakan label bahasa asing merupakan barang impor yang diedarkan di Indonesia tanpa membuat label versi bahasa Indonesia. Contoh barang-barang dengan label bahasa asing biasanya berupa produk obat, makanan ringan, dan barang elektronik. Hal ini dapat merugikan konsumen Indonesia karena mereka tidak dapat mengetahui keterangan produk 
seperti komposisi bahan, aturan pakai, serta efek samping.

Contoh produk obat tanpa label bahasa Indonesia adalah Ozen Cetirizine 2 $\mathrm{HCl}$ ukuran 12 ml (kode obat keras, harga Rp. 85.000). Ozen Cetirizine diproduksi oleh PT Pharos Indonesia yang berlokasi di Jakarta Selatan. Produk Ozen yang masuk dalam kategori obat keras tanpa disertai label/informasi produk dalam bahasa Indonesia dapat menyulitkan konsumen lokal dalam menggunakan obat tersebut karena informasi yang tersedia hanya dalam bahasa Inggris. Alasan produsen memilih bahasa Inggris dibandingkan bahasa Indonesia dapat dikaitkan dengan pangsa pasar dan harga obat. Harga yang cukup mahal untuk ukuran pendapatan masyarakat Indonesia dapat menjadi alasan produsen memilih label berbahasa Inggris agar memunculkan persepsi bahwa harga mahal berasosiasi dengan barang impor, meskipun obat Ozen adalah produksi lokal. Produk obat yang menggunakan label bahasa asing tanpa disertai bahasa Indonesia dapat dijumpai di toko obat atau apotek, sedangkan makanan ringan yang berlabel bahasa asing tanpa disertai dengan terjemahannya terutama dapat dijumpai di supermarket yang menyediakan produk-produk impor misalnya di supermarket Hero, K-Mart, Ranch Supermarket, Cosmo, Rezeki Swalayan, dan lainnya (diolah dari berbagai sumber daring).

Produk-produk impor dengan label bahasa asing tanpa terjemahan bahasa Indonesia cukup diminati oleh kalangan menengah ke atas dan anak muda. Produk impor dianggap lebih bergengsi dan berkualitas. Ciri khas produk impor yang dipahami oleh masyarakat umum adalah produk tersebut tanpa label berbahasa Indonesia. Hal ini menjadi persoalan mendasar bagi konsumen yang tidak dapat membaca label berbahasa asing. Mereka tidak dapat mengetahui komposisi dan aturan pakai dan dampaknya dapat merugikan terutama dari sisi kesehatan. Bahkan di negara dengan mayoritas muslim seperti Indonesia, tentu sangat penting mengetahui komposisi produk makanan atau obatobatan bebas dari kandungan babi, alkohol, atau arak dalam bahasa Indonesia.

Produk yang beredar di Indonesia tanpa disertai dengan label berbahasa Indonesia menyalahi hak konsumen yang tertuang dalam Undang-Undang RI No. 8 Tahun 1999 BAB III Pasal 4C: "Hak mendapat informasi yang benar, jelas, dan jujur atas kondisi dan jaminan barang dan/atau jasa, karena konsumen yang menggunakan produk tanpa label berbahasa Indonesia tidak mendapat informasi yang benar dan jelas karena konsumen lokal tidak dapat memahami informasi dengan baik dalam bahasa asing sehingga dikhawatirkan akan berimplikasi pada salah penggunaan/pemakaian produk. Jika dilihat dari sisi pengusaha, pemberian label berbahasa Indonesia dapat dianggap cukup merepotkan karena harus mengubah kemasan/label. Secara umum label berbahasa asing dan/tanpa bahasa Indonesia untuk produk yang beredar di Indonesia bertentangan dengan UndangUndang No. 24 Tahun 2009 Bab III Tentang Bahasa Pasal 37 ayat 1 yaitu, "Bahasa Indonesia wajib digunakan dalam informasi tentang produk barang atau jasa produksi dalam negeri atau luar negeri yang beredar di Indonesia". Pada ayat 2, 
informasi tentang produk dan jasa tersebut dapat dilengkapi dengan bahasa daerah atau bahasa asing sesuai dengan kebutuhan. Penekanan informasi pada ayat 2 ada pada kata“"'dapat dilengkapi'"'artinya penggunaan bahasa Indonesia tetaplah yang utama. Produk impor yang diedarkan di Indonesia minimal harus disertai dengan label terjemahan dalam bahasa Indonesia.

Fenomena label berbahasa asing juga bertentangan Undang-Undang RI No.7 Tahun 2014 pasal 6 ayat 1 yang berbunyi: “"Setiap Pelaku Usaha wajib menggunakan atau melengkapi label berbahasa Indonesia pada barang yang diperdagangkan di dalam negeri”. Serta bertentangan dengan Peraturan Menteri Perdagangan Republik Indonesia Nomor 67/MDAG/PER/11/2013 Tentang Kewajiban Pencantuman Label dalam Bahasa Indonesia pada Barang pasal 2 ayat 1 yang berbunyi, "Pelaku Usaha yang memproduksi atau mengimpor Barang untuk diperdagangkan di Pasar dalam negeri sebagaimana tercantum dalam Lampiran Peraturan Menteri ini wajib mencantumkan Label dalam Bahasa Indonesia”. Ayat lanjutan dalam pasal 2 juga menyatakan bahwa bahasa Indonesia pada label produk hendaknya digunakan secara ringkas dan jelas, dengan pengecualian bahasa asing dapat digunakan bila tidak ada padanannya dalam bahasa Indonesia.

Sanksi yang diberikan bagi produsen yang tidak menggunakan atau melengkapi label berbahasa Indonesia tercantum dalam UndangUndang RI No.7 Tahun 2014 pasal 104 yang berbunyi, "Pelaku Usaha yang tidak menggunakan atau melengkapi label berbahasa Indonesia pada
Barang yang diperdagangkan di dalam negeri sebagaimana dimaksud dalam pasal 6 ayat (1) dipidana dengan pidana penjara paling lama 5 (lima) tahun dan/atau pidana denda paling banyak Rp. 5.000.000.000, 00 (lima miliar rupiah)". Penegakan hukum terkait label berbahasa asing di dalam negeri masih bersifat semu karena walaupun ancaman pidananya cukup besar namun hingga hari ini masih banyak produk yang beredar di Indonesia tidak menggunakan atau melengkapi label produk berbahasa Indonesia.

\section{Kontra produktif kebijakan pemerintah tentang penggunaan bahasa Indonesia dalam bidang ekonomi}

Selain sikap berbahasa pelaku ekonomi Indonesia yang cenderung memilih penamaan bahasa asing, sikap pemerintah di sisi lain ternyata juga menunjukkan inkonsistensi dalam menjalankan amanat Undang-Undang No. 24 Tahun 200 Bab III Tentang Bahasa. Pemerintah telah menghapus pasal yang mengatur persyaratan kewajiban berbahasa Indonesia bagi tenaga kerja asing dalam rancangan peraturan menteri sebelum disahkannya Peraturan Menteri Tenaga Kerja No. 16 Tahun 2015 dengan alasan bahwa, penghapusan wajib berbahasa Indonesia itu merupakan bentuk dukungan bagi kebijakan investasi, dengan alasan syarat penguasaan bahasa Indonesia banyak dikeluhkan oleh para investor (http://m.republika.co.id/berita/nasional/politik/15 /08/25/ntllae328-syarat-berbahasa-Indonesiadihapus-serbuan-asing-kian-tak-terbatas/). Hal ini sempat menjadi polemik bagi banyak kalangan, mulai akademisi, pengamat bahasa dan budaya, 
anggota DPR RI, serta kalangan buruh karena pemerintah dianggap mengabaikan perlindungan terhadap pekerja Indonesia terutama kelompok buruh kasar.

Menurut data BPS, jumlah TKA selama Januari 2016 tercatat sebanyak 25.200 kunjungan kerja paruh waktu atau meningkat 69,3\% dibandingkan Januari 2015. Sedangkan menurut IMTA (Ijin Memperkerjakan Tenaga Kerja Asing) jumlah TKA selama tahun 2015 sebanyak 69.025 orang dan 5300 orang selama Januari 2016 (m.detik.com/finance/read/2016/03/10/13937/316 187/4/mea-berlaku-5300-tenaga-kerja-asingbekerja-di-indonesia/). Bahkan dalam kesempatan yang sama, majalah Tempo mengulasnya sebagai berita utama dengan menyebutkan bahwa sebelum disahkannya Permenakertrans No. 16 Tahun 2015, Indonesia telah "kecolongan" tenaga kerja asing yang sebagian besar merupakan TKA buruh kasar dari China. Dalam ulasannya, penghapusan persyaratan bahasa Indonesia bagi TKA dianggap sebagai kebijakan yang tidak tepat karena tenaga kerja Indonesia tidak lagi memiliki perlindungan di saat pengangguran terus meningkat akibat kesulitan ekonomi (Tempo, Serbuan Buruh Tiongkok, 2015).

Permenakertrans tersebut juga tidak selaras dengan Undang-Undang No. 24 pasal 33 ayat 1 yang berbunyi, "Bahasa Indonesia wajib digunakan dalam komunikasi resmi di lingkungan kerja pemerintah dan swasta", dan ayat 2 yang berbunyi“"'Pegawai di lingkungan kerja lembaga pemerintah dan swasta sebagaimana dimaksud pada ayat (1) yang belum mampu berbahasa Indonesia wajib mengikuti atau diikutsertakan dalam pembelajaran untuk meraih kemampuan berbahasa Indonesia". Merujuk pada peraturan tersebut, maka bahasa Indonesia tidak lagi wajib digunakan dalam komunikasi resmi di lingkungan kerja serta TKA tidak memiliki kewajiban untuk mempelajari bahasa Indonesia.

Penggunaan bahasa Indonesa dalam nota kesepahaman/perjanjian juga diatur dalam Undang-Undang No. 24 Tahun 2009 pasal 31 yang berbunyi,"“"Bahasa Indonesia wajib digunakan dalam nota kesepahaman atau perjanjian yang melibatkan lembaga negara, instansi pemerintah Republik Indonesia, lembaga swasta Indonesia atau perseorangan warga negara Indonesia”. Pasal tersebut merinci bahwa nota kesepahaman/perjanjian harus ditulis dalam bahasa Indonesia dan bahasa asing bagi pihak asing.

Tahun 2010 sempat terjadi kegaduhan setelah disahkannya undang-undang tersebut karena banyak surat perjanjian dan kontrak kerja yang ditulis dalam bahasa Inggris, dikhawatirkan perjanjian yang ditulis dalam bahasa asing rentan dibatalkan demi hukum karena terbentur dengan isi undang-undang bahasa. Menteri Hukum dan Ham tahun 2010, Patrialis Akbar, yang saat itu menjabat justru memberikan surat klarifikasi bahwa surat perjanjian atau kontrak kerja yang tidak disertai dan tidak berbahasa Indonesia dinyatakan tetap sah dan tidak batal demi hukum, bahkan menyatakan bahwa isi undang-undang bahasa baru berlaku setelah ada peraturan presiden (pada pasal 40), serta menyatakan bahwa bila terjadi perbedaan penafsiran terhadap kata, frase, atau kalimat dalam bahasa Inggris dan bahasa Indonesia dalam suatu perjanjian, maka yang digunakan dalam 
menafsirkan kata, frase, atau kalimat dimaksd adalah versi bahasa Inggris. Pernyataan ini justru menimbulkan kontroversi di kalangan pengamat hukum karena undang-undang yang telah disahkan maka sifatnya mengikat tanpa harus menunggu peraturan

presiden

(http://www.hukumonline.com/berita/baca/lt4b6a 1df8b9cbf/menkumham-perjanjian-berbahasainggris-tetap-sah).

Bila dikaitkan lebih jauh, kebijakan pemerintah melalui undang-undang dan peraturanperaturan menjadi kontra produktif satu dengan lainnya sehingga menyebabkan negara tidak memiliki daya paksa bagi warga negara Indonesia dan warga negara asing untuk mempelajari dan menggunakan bahasa Indonesia. Hal ini bertolak belakang dengan cita-cita pemerintah menjadikan bahasa Indonesia sebagai bahasa nasional dan bahasa internasional yang tercantum dalam UU No. 24 Tahun 2009 pasal 44.

\section{Kesimpulan}

Sikap pelaku ekonomi yang lebih mengutamakan bahasa asing dibandingkan bahasa Indonesia dapat mengancam kedaulatan bahasa Indonesia. Bahasa Indonesia sulit mempertahankan bahkan mengisi posisi penting dalam percaturan komunikasi dunia bila masyarakat Indonesia masih menunjukkan kekaguman yang berlebihan terhadap budaya dan bahasa asing. Fenomena xenofilia bahasa asing di masyarakat ekonomi cukup banyak bermunculan namun kondisi ini tidak disadari sebagai bentuk ancaman bagi kelestarian kearifan lokal bahasa Indonesia. Hal ini bertolak belakang dengan amanat undang-undang bahasa dalam menjaga, melestarikan, dan mengantarkan bahasa Indonesia sebagai bahasa internasional.

Upaya kebijakan pemerintah Indonesia untuk membina dan melindungi bahasa Indonesia sebagai bagian dari kekayaan bangsa ternyata tidak berbanding lurus dengan kenyataan sikap berbahasa masyarakat. Hal ini disebabkan semangat mencintai dan mengunggulkan bahasa Indonesia masih bersifat semu atau dekoratif. Alihalih kebijakan tersebut diikuti oleh masyarakat, pemerintah pun tidak luput dari ketidakpatuhan terhadap undang-undang tentang bahasa. Di sisi lain, kebijakan yang dibuat justru menjadi kontra produktif bagi pelaku ekonomi dimana prinsip utama dalam bisnis adalah mencari keuntungan semaksimal mungkin dengan upaya seminimal mungkin atau semudah mungkin, sedangkan peraturan untuk menggunakan atau mengubah nama merek, nama lembaga usaha, nama bangunan/properti/pemukiman, keterangan merek berbahasa Indonesia dianggap bagian dari inefisiensi produksi dan berlawanan dengan strategi pemasaran. Pemerintah seharusnya konsisten menegakkan peraturan dan memberikan sanksi bagi pelanggar sebagai bentuk keteladanan serta preseden baik sekaligus menyediakan jalan tengah bagi para pelaku ekonomi agar terbuka menerima kebijakan berbahasa Indonesia, karena bahasa Indonesia hendaknya menjadi kekayaan dan identitas lokal yang mampu menjadi daya tarik konsumen baik lokal maupun internasional. 
Sebagai bentuk kontribusi bagi penelian yang akan dilakukan di masa depan, disarankan untuk melakukan pendekatan tidak hanya behavioris melainkan mentalis sehingga interpretasi menjadi lebih luas dan mendalam mengingat pelaku bisnis dilibatkan sebagai subyek penelitian yang berkontribusi untuk menghasilkan interpretasi dari sikap bahasa yang terlibat dalam pelebelan produk. Di samping itu, data primer dibutuhkan untuk lebih meningkatkan tingkat kebaruan temuan. Berikutnya penelitian juga dapat dilakukan dengan mengarah pada perubahan bahasa sebagai hasil atau konsekuensi sikap bahasa.

\section{Daftar Pustaka}

Annika Hohenthal, Department of English, University of Turku, Finland. http://www.postcolonialweb.org/india/hoh enthal/6.1.html. Diakses 1 September 2016

Azhar, Iqbal Nurul. (2010). Sikap Bahasa (Language Attitude). https://pusatbahasaalazhar.wordpress.com/ hakikat-hakiki-kemerdekaan/sikap-bahasalanguage-attitude/ (daring). Diakses pada 28 Agustus 2016.

Azwar, S. (2007). Sikap Manusia Teori dan Pengukurannya. Edisi 2. Yogyakarta: Pustaka Pelajar.

Chaer, Abdul dan Leonie Agustina. (2004). Sosiolinguistik Perkenalan Awal. Jakarta: Rineka Cipta.

Elena Villar, M., Di Ai, and Sigal Segev. (2012). Chinese and American perceptions of foreign-name brands', Journal of Product \& Brand Management, 21 (5), pp. 341-349. doi: $10.1108 / 10610421211253632$.

Fasold, R. (1984). Sociolinguistics of Society. Basil black Well Inc. New York.

Gao, Y., Su, X. And Zhou, L. (2000). Prehandover language attitudes in Hongkong, Beijing, and Guangzhou in Limei Wang a \& Hans J. Ladegaard (2010) Language Attitudes and Gender in China: Perceptions and Reported Use of Putonghua and Cantonese in the Southern Province of Guangdong.

http://202.116.197.15/cadalcanton/Fulltext/ 21510_201443_113651_116.pdf. Diakses pada 5 September 2016.

Halliday, M.A.K. \& R. Hasan diterjemahkan oleh Barori. (1992). Bahasa, Konteks, dan Teks.: Aspek-Apek Bahasa dalam Pandangan Semiotik Sosial. Gadjah Mada University Press.

Hoare, R. (2000). An Integrative approach to language attitudes and identity in Brittany. Journal of Sociolinguistics, 2(1),73-84 http://onlinelibrary.wiley.com/doi/10.1111/ 1467-9481.00138/pdf, Diunduh pada 2 September 2016

Ihemere, Kelechukwu Uchechukwu. (2006). "An Integrated Approach to the Study of Language Attitudes and Change in Nigeria: The Case of the Ikwerre of Port Harcourt City". In Selected Proceeding of the 36th Annual Conference on African Linguistics, ed. Olaoba F. Arasanyin and Michael A. Paemberton A, 194-207. Somerville, MA: Cascadilla Proceedings Project. http://www.lingref.com/cpp/acal/36/paper1 424.pdf. Diakses 1 September 2016.

Kridalakasana, Harimurti. (2001). Kamus Linguistik. Jakarta: PT Gramedia Pustaka Utama.

Lambert, Wallace E. (1967). A Social Psychology of Bilingualism. 91-109. Journal of Social Issues. Volume 23. Issues 2. (online) 14 April 2010.

Maricar, Farida. (2016). The Influence Factors of Ternate Language Shift in Ternate City. International Journal of Science and Research (IJSR). Vol 5 Issue 1, January 2016. pp. $1756-1761$.

Sari, Siti Purnama. (2014). Analisis Pengaruh Foreign Branding terhadap Perceived Product Advantage dan Brand Image serta Implikasinya terhadap Minat Membeli Produk Lea Jeans. Skripsi. http://eprints.undip.ac.id/44641/1/14_SITI. pdf (online). Diakses pada 28 Agustus 2016.

Suprana, Jaya. (2009). Naskah-Naskah Kompas. Jakarta: Elex Media Komputindo.

Yenata, Sany Tifani dan F. Anita Herawati. (2016) Pengaruh Tingkat Ketertarikan pada Desain Logo dan Nama Merek Terhadap 
Brand Image (Studi Eksplanatif Mengenai Pengaruh Tingkat Ketertarikan pada Desain Logo dan Nama Merek Terhadap Brand Image Zupparella. https://core.ac.uk/download/files/886/3538 9457.pdf (daring). Diakses 29 Agustus 2016. 